\begin{tabular}{lc} 
SCIENCE \& TECHNOLOGY \\
Journal homepage: http://www.pertanika.upm.edu.my/ \\
\hline PERTANIKA
\end{tabular}

Review article

\title{
Impact of Climate Change on Migratory Birds in Asia
}

\author{
Nurhafizul Abu Seri and Azimah Abd Rahman* \\ Geoinformatic Unit, Geography Section, School of Humanities, Universiti Sains Malaysia, 11800 USM, \\ Pulau Pinang, Malaysia
}

\begin{abstract}
Climate change is not something that has never happened before. However, it has recently been reported that climate change has affected living things such as humans, animals and plants. Among the animals that may be vulnerable to the effects of climate change are migratory bird species. Therefore, this review paper will emphasise the checklist of migratory bird species found to be affected by climate change. Data for bird migration species in Asia are obtained from the Birdlife Data Zone. At the same time, the data for Global land surface temperature (1910-2020) and Asia land surface temperature (1910-2020) were taken from National Oceanic and Atmospheric Administration for Environmental information. These papers showed that climate warming could affect species differently, but there are still species from certain populations not affected at all. This paper also reviewed that approximately 169 species of migratory birds in Asia are affected by climate change and severe weather. Of the total, 5 species $(2.96 \%)$ are critically endangered, 8 (4.73\%) endangered, 21 (12.43\%) vulnerable, 27 (15.98\%) near threatened and $123(63.91 \%)$ least concern.
\end{abstract}

Keywords: Asia, climate change, migratory birds, species, temperature

\begin{tabular}{|c|c|}
\hline & INTRODUCTION \\
\hline ARTICLE INFO & $\begin{array}{l}\text { Overharvesting may be one of the most } \\
\text { persistent threats to migratory birds because }\end{array}$ \\
\hline $\begin{array}{l}\text { Article history: } \\
\text { Received. } 27 \text { nnil } 2021\end{array}$ & of human exploitation of their biology, \\
\hline Accepted: 30 July 2021 & including predictable spatiotemporal \\
\hline Published: 28 October 2021 & peaks in large quantities at various scales \\
\hline DOI: https://doi.org/10.47836/pjst.29.4.38 & (Shuter et al., 2011). Nevertheless, today, \\
\hline $\begin{array}{l}\text { E-mail addresses: } \\
\text { nurhafizul.abuseri97@gmail.com (Nurhafizul Abu Seri) } \\
\text { azimahrahman@usm.my (Azimah Abd Rahman) } \\
\text { * Corresponding author }\end{array}$ & $\begin{array}{l}\text { overharvesting is no longer the only major } \\
\text { threat to migratory birds because of the }\end{array}$ \\
\hline
\end{tabular}


emergence of a new threat that may have occurred over a long period. However, it has not been realised at that time that is climate change. Turrin and Watts (2016) assessed and calculated the sustainable harvest threshold for Asia-Pacific migratory shorebirds. Global climate change has a significant effect on the phenology of seasonal events (Lehikoinen et al., 2004; Ahas \& Aasa, 2006; Menzel et al., 2006), and it has the potential to alter migration phenology (Both \& te Marvelde, 2007; Rubolini et al., 2007).

Climate change can cause specific problems for migratory birds living in different parts of the annual cycle in other world regions (Sillett et al., 2000). One of the most crucial concerns is climate change when global surface temperatures have warmed at an average of $0.16^{\circ} \mathrm{C}$ to $0.18^{\circ} \mathrm{C}$ per decade since the 1970 s (Solomon et al., 2007). The 2013 Intergovernmental Panel on Climate Change predicts that if the present pattern in emissions continues, global temperatures are expected to rise by $2^{\circ} \mathrm{C}$ or as much as $4.8^{\circ} \mathrm{C}$ by 2100 (Collins et al., 2013; Pachauri et al., 2014).

One of the most interesting facets of birdlife is migration. They get the ability to migrate hundreds or thousands of kilometres across geographical boundaries to other parts of the globe in response to changes in habitat, food availability, climate, and other factors. For example, there are almost 828 species of migratory birds in Asia, while in Europe, there are 429 species. However, many migration birds, mammals, fish, and invertebrates have experienced population loss in previous centuries (Wilcove \& Wikelski, 2008; Gilroy et al., 2016). Therefore, a large number of migratory birds use flyways as their flight path. A flyway is a biological system consisting of entire types of migratory bird species, related communities of species, or different populations of one species that migrate annually from breeding areas to non-breeding areas, including a stopover and feeding areas as well as migration areas (Bridge et al., 2007).

The Eastly-Australasian Flyway (EAAF) is an important flyway in Asia that is also one of the nine major routes used by migratory birds. This EAAF flyway, which crosses three continents and 22 countries, is one of the world's biggest and most species-rich migration corridors (Turrin \& Watts, 2016). Apart from the EAAF, the West Pacific Flyway and West Asian Flyway are two of the three flyways available in Asia. As a consequence, determining the migration paths and stopovers of migratory animals is important for effective population management and habitat conservation (Hutto, 2000; Faaborg et al., 2010). However, this review will not concentrate on a single migratory bird route in Asia but the total migratory birds observed in Asia from different flyways. First, the purpose of this study is to identify and list the species of avian (migratory birds) found in Asia that affected reference to previous studies that analysed the relationship between climate change and migratory birds. Second, the goal of this study was to identify migratory bird species in Asia that are sensitive to the impact of climate change, which may contribute to species loss. This information is essential for designing new conservation strategies and prioritising the endangered species and critically endangered species. 


\section{THE CLIMATE-CHANGING SINCE 1910-2020}

The primary data sources for migration bird checklists found in Asia used in this article are obtained from the Birdlife Data Zone. Species threat data on climate change and extreme weather for birds migrating in Asia were also collected from the Birdlife Data Zone. All data observed are the latest updated until 23 February 2021. Meanwhile, data for Global land surface temperature (1910-2020), Asia land surface temperature (1910-2020) were taken from NOAA National Centers for Environmental information (2021). According to the International Union for Conservation of Nature (IUCN), the conservation status of migratory bird species was identified.

The earth's climate has changed over a long period until now, which has seen a very significant change. The tropopause, the border between the stratosphere and the troposphere, has climbed several hundred metres in height since 1979. Human-induced increases in ozone and mixed greenhouse gases account for approximately $80 \%$ of the simulated tropopause height increase from 1979 to 1999 (Santer et al., 2003). One of the most commonly used measures of global climate change is the global average temperature, and it has shown a series of increases since the early twentieth century. Natural processes, as well as certain impacts from human activity, lead to year-to-year temperature changes.

Figures 1 and 2 show the global land temperature anomalies from January to December for 1910 to 2020. Based on Figure 1, the negative anomaly (colder than normal) occurred around 1910 to 1937 before it fell to a positive anomaly (warmer than normal) in 1938 to 1944 . The decline from negative anomalies in 1910 to 1937 to positive anomalies in a subsequent year shows evidence that there had been changes in terms of global climate around the 90s. Since then, annual anomalies for global surface temperatures have been seen as erratic and often change almost every year. For example, several other negative anomalies have occurred before 2000, namely in 1945 to 1946,1949 to 1952,1954 to 1957 , 1960, 1964 to 1966,1968 to 1969,1971 to 1972 and 1974 to 1976 . While the positive anomalies that occurred before the year 2000 were in 1947 to $1948,1953,1958$ to 1959 , 1961 to $1963,1967,1970,1973,1975,1977$ to 1999 . Then, from 2000 to 2020, all those years recorded only positive anomalies marked since the beginning of the 20 s era of global surface temperature conditions were warming. Therefore, based on all the data shown and proved from 1910 to 2020 , there has been a change in global climate. In conclusion, climate change has occurred globally, increasing land temperature anomaly from $-0.36^{\circ} \mathrm{C}$ (cold) in 1910 to $1.59^{\circ} \mathrm{C}$ (hot) in 2020 .

Figure 2 shows the Asia land temperature anomalies from January to December for the years 1910-2020. In Asia, around 1910 to 1976 (66 years), the majority of those years were to record the negative land temperature anomaly. However, there were still some years that showed warmer than normal conditions (positive anomaly). The hot years were 1914, 1925, 1932, 1938 to 1939,1943 to $1944,1948,1951,1953,1959,1961$ to $1963,1967,1971$, 


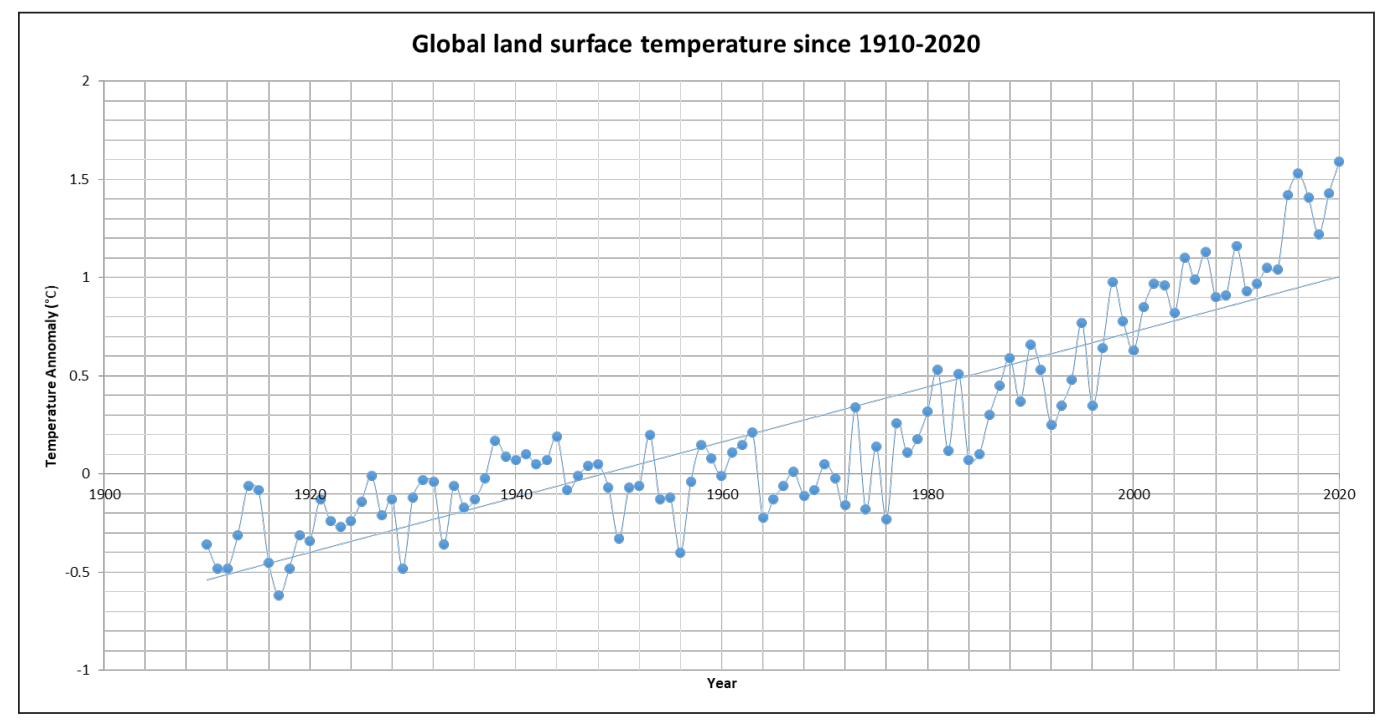

Figure 1. Global land surface temperature anomalies from 1910 to 2020

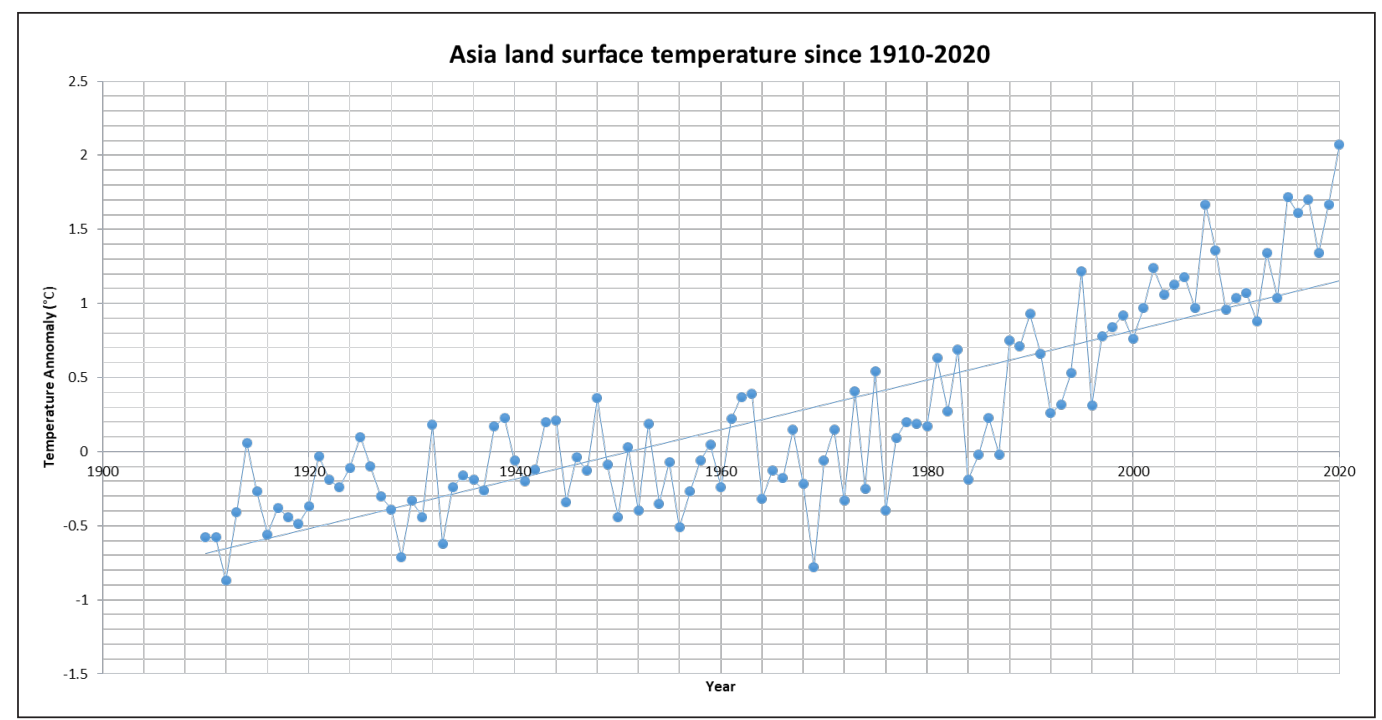

Figure 2. Asia's land surface temperature anomalies from 1910 to 2020

1973 and 1975. Later in the year, 1977 to 1983 also showed positive anomalies before the next two years recorded negative anomalies in 1984 to 1985. From 1988 to 2020, all these years recorded a positive anomaly which means that the land surface temperature in Asia is warming up in the 20s. It can be concluded here that there has been climate change in Asia when there was an increase in land temperature anomaly from $-0.58^{\circ} \mathrm{C}$ (cold) in 1910 to $2.07^{\circ} \mathrm{C}$ (hot) in 2020 . Land temperature anomaly in 2020 is quite high if compared to previous years because it has exceeded $2^{\circ} \mathrm{C}$. 


\section{THE CATASTROPHE OF CLIMATE CHANGE ON MIGRATORY BIRDS- THE EVIDENCE}

For decades, researchers have studied the impact of daily weather variations on the number of birds that have avoided migration. During the 1960s and 1970s, when some radar and visual experiments on migration were performed, the research was particularly active (Richardson, 1990). Rising temperatures are the most significant factor affecting bird migration trends, forcing birds to migrate a little early each spring and change the return journey by less than two days per decade (Richardson, 1990; Horton et al., 2020). As a result, migratory species may need to adapt their seasonal and annual migration patterns to avoid entering areas with extreme climates such as too cold, too hot, too low humidity, too high humidity, and to use new habitats in areas with previously low temperatures and humidity. In response, the distribution of species may vary (Langham et al., 2015). For example, it has been found that large bustard migration patterns of males (but not females) are closely related to extreme temperatures during the summer breeding season (Alonso et al., 2009).

In addition to forcing birds to migrate a little earlier, changes in temperature associated with climate change are expected to result in a reduction in body size, a primary determinant of animal physiology and ecology (Weeks et al., 2019). Thus, climate change, regarded as one of the most serious threats to biodiversity and ecosystems, may impact migratory bird distribution and survival (Liang et al., 2018). Additionally, a number of additional studies have forecasted changes in species richness or distribution in China as a result of climate change scenarios (Hu et al., 2017; Liang et al., 2018). It may also be concluded that animals have evolved to withstand extreme temperatures, and climate change has had a significant effect on species physiology, including increases in exposure to elevated temperatures, differences in sex ratios in species with temperature-dependent sex, and increased metabolic costs associated with living in a warmer environment (Scheffers et al., 2016).

However, trying to forecast which components of climate have the most influence on species distribution is one of the issues confronted by ecologists and conservation biologists (Bateman et al., 2015). Furthermore, the potential consequences of climate change on bird distribution have been explored extensively today, such as polar or shortrange winter breeding distances by La Sorte et al. (2017) and Wauchope et al. (2017). The influence of climate change on food sources and the habitat of migratory bird species has been highlighted as one of the most critical components in migratory bird research (Walther et al., 2002). It is proven that the consequences of recent climate change have been discovered to affect migratory bird migration patterns (Both et al., 2006; Harris et al., 2013). According to Harries et al. (2013), climate change causes a shift in migration time for some birds in Southeast Asia. The reason for this delay of long-distance migrants is that warmer temperatures allow species to stay in northern breeding sites longer. Delayed arrivals in winter places may have a tiering influence on migratory species' yearly cycles, 
such as changing the arrival date in breeding places, which can influence fitness. Harries et al. (2013) discovered a 1 to 3 days arrival delay in the Japanese sparrowhawk Accipiter gularis and the sandpiper curlew Calidris ferruginea, but no change in the arrival date for the other species.

As a result, the timing of bird migration has served as a useful framework for researching how natural processes react to climate change (Hurlbert \& Liang, 2012; Jonzen, 2006). It was discovered that animals arriving late in the migration phase might have difficulty developing breeding areas or finding compatible partners (Møller, 2001; Pulido, 2007; Faaborg et al., 2010). According to a number of surveys have been done by Hughes (2000), McCarty (2001), Ottersen et al. (2001), and Wuethrich (2000), the current climate change has affected a diverse range of animals with geographically distributed regional ranges. Pacifici et al. (2017) showed that climate change has already impacted a significant number of endangered species populations by modelling the interaction between observed and inherent responses and spatial properties. Climate change could have harmed at least $47 \%$ of non-terrestrial endangered mammals ( 873 species) and $23.4 \%$ of endangered birds $(1,272$ species $)$ in at least part of their range, according to the study's findings (Pacifici et al., 2017).

According to atmospheric conditions in the $21^{\text {st }}$ century, the ideal migration site between Japan and China occurred in the East China Sea (2006-2013) (Figure 3) (Nourani et al., 2017). According to their findings, the expected changes in atmospheric conditions

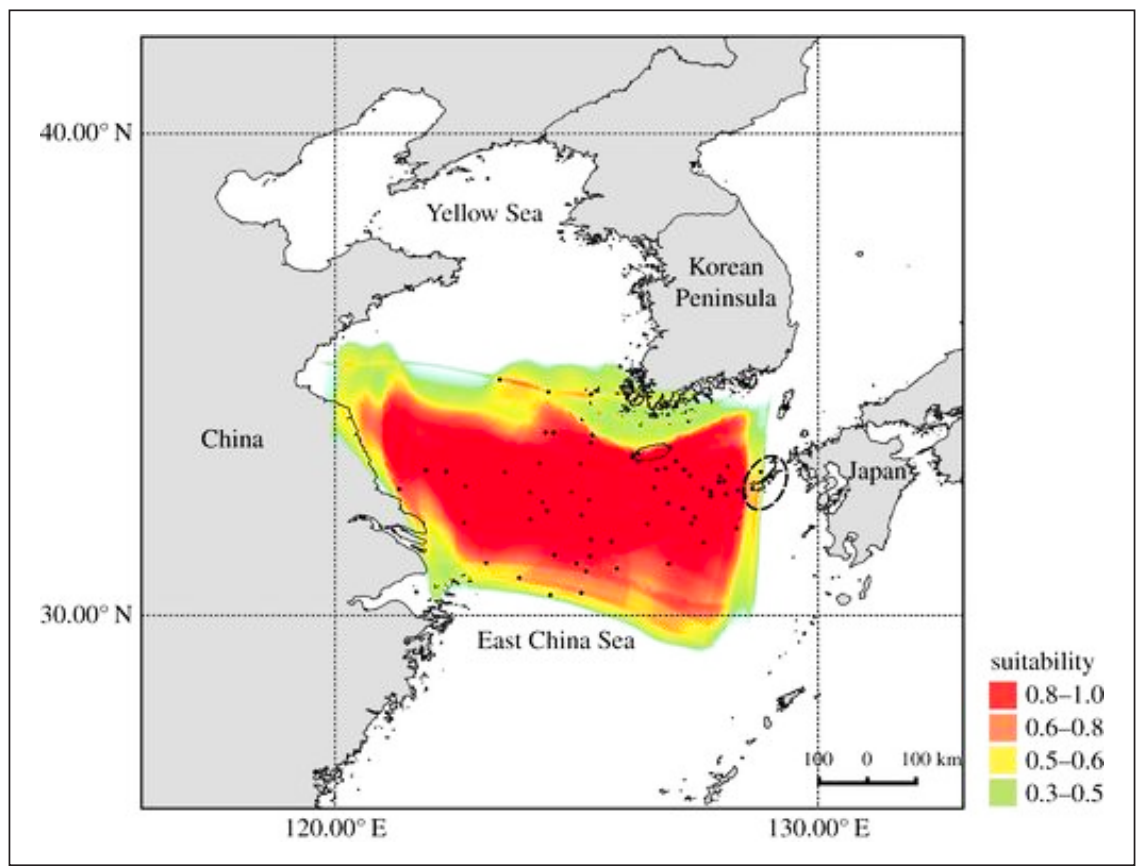

Figure 3. Ensemble model projections for suitable atmospheric conditions for the fall migration of Oriental honeybuzzards (2006-2013) (Nourani et al., 2017) 
caused by climate change may have a negative impact on the suitability of traditional bird migration routes. Under the RCP4.5 scenario, suitable areas will move northward in the middle of this century. Highly suitable areas' scope and connectivity will suffer greater loss (Figures $4 \mathrm{a} \& 4 \mathrm{~b}$ ), resulting in more severe conditions. However, by the turn of the century, the model identified a suitable area in the eastern part of the Korean Peninsula under RCP4.5 (Figure 4c) and a moderately small area under RCP8.5 (Figure 4d). Both deviate from the traditional route and cannot provide a complete route from Japan to China. Thus, it can be said that climate change has changed the best wind-dependent flight routes for bird migration.

Warren et al. (2013) undertook a global study of potential climate range transitions from common and prevalent species. They found that, there would be $57 \pm 6 \%$ of plants without mitigation, and $34 \pm 7 \%$ of animals would lose $50 \%$ of their climate range by the $2080 \mathrm{~s}$. However, if emissions plateau in 2016 , losses are reduced by $60 \%$, and if emissions peak

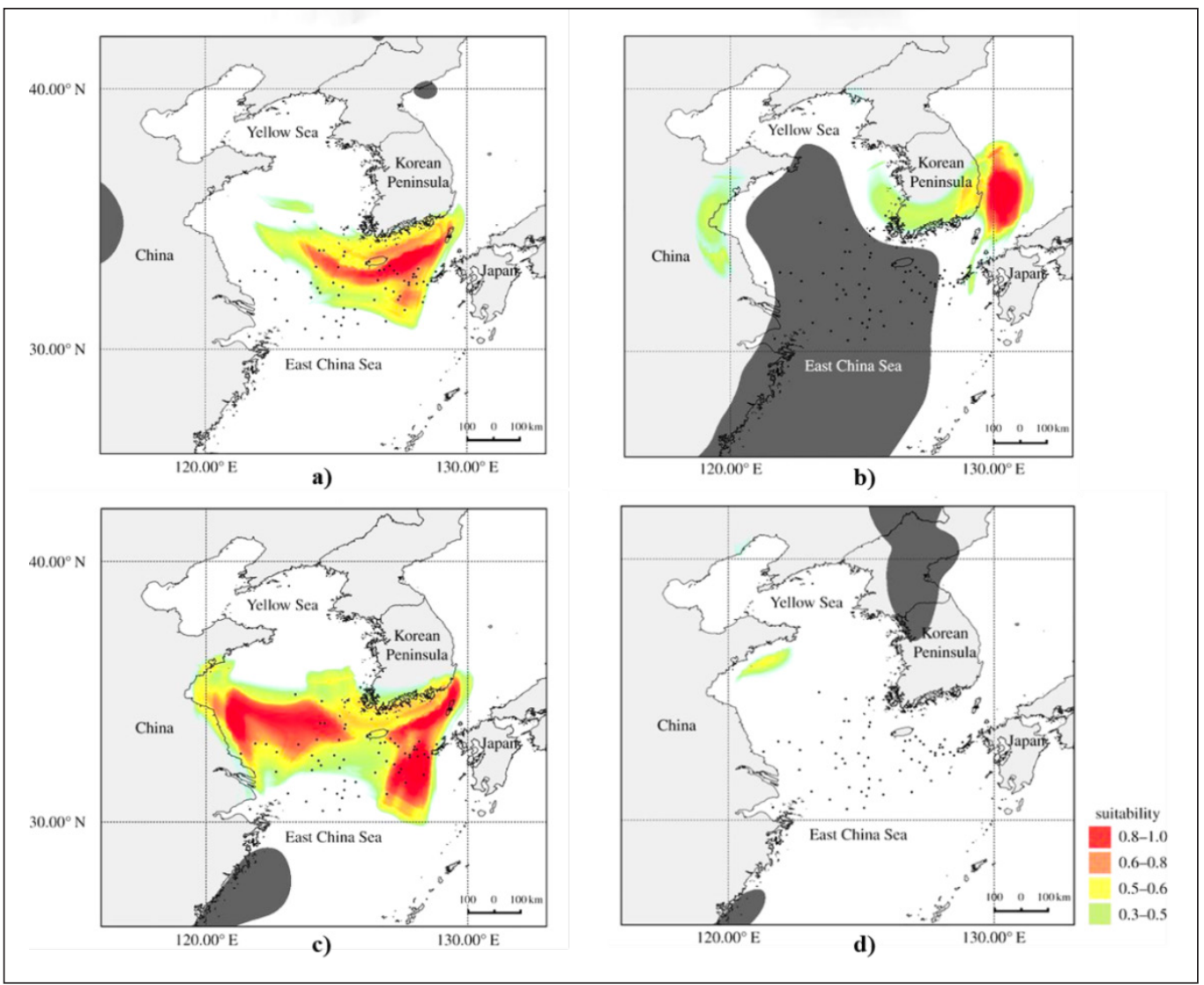

Figure 4. Ensemble model projections for suitable atmospheric conditions for the fall migration of Oriental honeybuzzards: (a) mid-century (2046 to 2055; RCP4.5 scenario), (b) mid-century (2046 to 2055; RCP8.5 scenario), (c) late century (2091 to 2100 ; RCP4.5 scenario), and (d) late century (2091 to 2100; RCP8.5 scenario) (Nourani et al., 2017) 
in 2030 , losses are reduced by $40 \%$. With the influence of rising temperatures on animal species due to climate change, it can be projected that migratory birds are also likely to suffer the same fate or even worse. Because migratory birds are not a species in the areas they visit, they will face problems adapting to places other than their area of origin. Thus, it can be argued that migratory birds found in Asia may need help adapting to climate change to survive or live in an area. Table 1 shows the impact of climate change on different animal species that have occurred. Other animals such as turtles, whales, sharks, dolphins, and avian species are also affected by this climate change. Each animal was found to be affected by different climatic factors (Table 1).

Table 1

Climate change's effect on certain animal species (Trouwborst, 2012)

\begin{tabular}{|c|c|c|c|c|}
\hline Climate Impact & & Impact on Animal Species & & Animal Species \\
\hline $\begin{array}{l}\text { Temperatures are } \\
\text { rising }\end{array}$ & $\begin{array}{l}\text { b) } \\
\text { c) }\end{array}$ & $\begin{array}{l}\text { Melting sea ice has resulted in habitat } \\
\text { destruction; } \\
\text { Zooplankton density has changed; and } \\
\text { Sex ratios have changed. }\end{array}$ & a) & $\begin{array}{l}\text { Balaena Mysticetus } \\
\text { Cetorhinus Maximus } \\
\text { Dermochelys Coriacea }\end{array}$ \\
\hline $\begin{array}{l}\text { Changes in } \\
\text { Precipitation }\end{array}$ & b) & $\begin{array}{l}\text { Wetland habitat for breeding and feeding is } \\
\text { vanishing; } \\
\text { Grazing habitat for terrestrial mammals is } \\
\text { vanishing; and } \\
\text { Rainfall changes affect breeding } \\
\text { performance. }\end{array}$ & $\begin{array}{l}\text { a) } \\
\text { b) } \\
\text { c) }\end{array}$ & $\begin{array}{l}\text { Calidris Canutus Rufa } \\
\text { Addax Nasomaculatus } \\
\text { Gavialis Gangeticus }\end{array}$ \\
\hline Weather Extremes & $\begin{array}{l}\text { a) } \\
\text { b) }\end{array}$ & $\begin{array}{l}\text { Extremes of temperature; } \\
\text { Storm frequency and severity have } \\
\text { increased; and } \\
\text { Precipitation extremes have increased. }\end{array}$ & $\begin{array}{l}\text { a) } \\
\text { b) } \\
\text { c) }\end{array}$ & $\begin{array}{l}\text { Platanista Gangetica } \\
\text { Tadarida Brasiliensis } \\
\text { Trichechus Senegalensis }\end{array}$ \\
\hline Increasing Sea Levels & $\begin{array}{l}\text { a) } \\
\text { b) }\end{array}$ & $\begin{array}{l}\text { The loss of low-lying marine habitat; and } \\
\text { The disappearance of nesting areas. }\end{array}$ & $\begin{array}{l}\text { a) } \\
\text { b) }\end{array}$ & $\begin{array}{l}\text { Anser Cygnoides } \\
\text { Chelonia Mydas }\end{array}$ \\
\hline $\begin{array}{l}\text { Acidification of the } \\
\text { Oceans }\end{array}$ & $\begin{array}{l}\text { a) } \\
\text { b) }\end{array}$ & $\begin{array}{l}\text { Food web affected; and } \\
\text { Habitat degradation. }\end{array}$ & a) & $\begin{array}{l}\text { Eubalaena Japonica } \\
\text { Eretmochelys Imbricata }\end{array}$ \\
\hline $\begin{array}{l}\text { Ocean Circulation } \\
\text { Changes }\end{array}$ & b) & $\begin{array}{l}\text { Shifts in food distribution and abundance; } \\
\text { and } \\
\text { Migration-related impact. }\end{array}$ & a) & $\begin{array}{l}\text { Me g a p t e } r \text { a } \\
\text { Novaeangliae } \\
\text { Hawksbill Turtle }\end{array}$ \\
\hline $\begin{array}{l}\text { Spatial and Temporal } \\
\text { Responses }\end{array}$ & $\begin{array}{l}\text { a) } \\
\text { b) } \\
\text { c) }\end{array}$ & $\begin{array}{l}\text { Biome shifts; } \\
\text { Phenological shifts; and } \\
\text { Destruction of habitat. }\end{array}$ & $\begin{array}{l}\text { a) } \\
\text { b) } \\
\text { c) }\end{array}$ & $\begin{array}{l}\text { Puffinus Mauretanicus } \\
\text { Caretta Caretta } \\
\text { Grus Leucogeranus }\end{array}$ \\
\hline $\begin{array}{l}\text { Existing Threats are } \\
\text { Getting Worse }\end{array}$ & & - & a) & Acrocephalus Griseldis \\
\hline
\end{tabular}

The highest number of endangered migratory bird species has been identified in many locations. For example, the East Asia-Australasia Region has the highest percentage of endangered migratory waterbirds, which is $20 \%$. Although Africa, Eurasia, Central Asia, and East Asia-Australasia have the highest percentage of endangered birds (roughly $30 \%$ each), America, Africa, Eurasia, and East Asia-Australasia have the highest percentage of endangered seabirds (roughly $30 \%$ each). The East Asia-Australasia flyway has the highest 
number of endangered migratory waterbirds (19\%) when it comes to flyways. Though the Black Sea-Mediterranean, East Asia-East Africa, Central Asia, and East Asia-Australasia have the highest percentages of vulnerable soaring birds (between 24 and 34\%), the Black Sea-Mediterranean, East Asia-East Africa, Central Asia, and East Asia-Australasia have the lowest (Galbraith et al., 2014). Globally, 317 (14\%) migratory bird species are classified as endangered or near-threatened. According to the 2010 IUCN Red List, there are 17 critically endangered migratory bird species, 50 threatened migratory bird species, vulnerable migratory bird species, and near-threatened migratory bird species out of 317 migratory bird species (122). According to an overview of the number of species moving between Red List categories since 1988, 53 species have decreased in status, and only nine have improved (Galbraith et al., 2014).

Then, $\mathrm{Hu}$ et al. (2010) found that the black-faced spoonbill (Platalea minor) is an endangered migratory species confined to East Asia due to climate change. They also predicted that by 2080, the population of black-faced spoonbills in various regions in Asia, including northeastern Vietnam, Taiwan, and coastal areas around the South China Sea, might be drastically reduced. They also indicated that the centre of the expected spoonbill range will migrate northwards by as much as $240 \mathrm{~km}$ by $2020,450 \mathrm{~km}$ by 2050, and 600 km by (2080). Finally, Liang et al. (2018) utilised species distribution models (SDM) and climate data to forecast future changes in migratory birds species distribution and how the geographical expansion of these endangered birds may adapt to changing climates by 2050 under current and future climate scenarios in China. The findings suggest that migratory bird hotspots would likely remain downstream and in the centre of China's Yangtze River. At the same time, more species will likely dwell in the coastal areas of Bohai Bay and the Yellow Sea in the future. Also, according to the findings, the proportion of all migratory bird species distribution or hotspots for all endangered migratory bird species protected by national nature reserves (NNRs) in China is still low in 2050.

Besides that, Runge et al. (2015) found that only a small fraction of migratory birds receive appropriate protection across their breeding and wintering ranges throughout the world. Given that over half of the world's migratory bird populations are dropping, these findings, according to them, highlight the urgency with which we must work to protect migratory birds during their entire migratory cycle. According to the study, only $9 \%$ of 1451 migratory birds are sufficiently protected by sheltered locations at all phases of their yearly cycle, compared to $45 \%$ of non-migratory species (Runge et al., 2015). The long-distance migrating birds, which rely on an endogenous circannual rhythm to trigger their migration, face unique hurdles in reacting to changes due to their extensive seasonal movements (Briedis et al., 2017).

Climate change has been shown to alter morphology in butterflies, dragonflies, and birds, which results in colour changes (Karell et al., 2011; Kingsolver \& Buckley, 2015; Roulin, 2014; Zeuss et al., 2014). In addition, climate change can influence the timing of 
migratory species' arrival on breeding grounds or the initiation of breeding activities, as well as the availability of resources required for successful reproduction (Burgess et al., 2018; Franks et al., 2017; Møller et al., 2008; Mayor et al., 2017). When all of those phenological incompatibilities exist, it may result in lower reproductive success and population decline (Møller et al., 2008; Miller-Rushing et al., 2010; Dunn \& Møller, 2013). However, Mayor et al. (2017) suggest that migratory birds could be among the species most readily suited to climate change because of their ability to migrate fast over long distances. Again, Mayor et al. (2017) argue that migration responds to annual climate change, so additional annual climate change is unlikely to pose a challenge in terms of adaptation.

Perhaps climate change might not be the only factor affecting these migratory birds; human actions such as economic activities also play a role in migratory bird species disruption. For example, considering China as a case study, which is a country with fastrising economic activity, it has a significant impact on migratory bird stopover habitat (Ma et al., 2014; Kamp et al., 2015), resulting in dropping migratory bird populations (Runge et al., 2015). However, generally speaking, that economic activities are happening in China, and other countries in the world may also be among those contributing to climate change. Therefore, it suggests that indirectly the economic activities that have contributed to climate change will likely also contribute to the disruption of the stopover of migratory birds, their food and so on. The situation may worsen when the area that should be used as a stopover has lost the characteristics and to needs these migratory birds need while living in the areas even if only for a while.

According to Kamp et al. (2015), persecution and over-exploitation by humans are also one of the major causes of species extinction. Between 1980 and 2013, the Yellowbreasted Buntings (Emberiza aureola) population dropped by $84.3 \%$ to $94.7 \%$, and the species' range shrank by 5000 kilometres. Quantitative data gathered during police raids revealed that the species was illegally trapped along its East Asian flyway in China. As the consumption of Yellow-breasted Bunting and other songbirds has grown, it is once again suggested that causes of economic development and prosperity in East Asia are the reason for the decline (Kamp et al., 2015). It has been proven that climate change is not the only cause of the current disturbance and reduction in the population of migratory bird species; other causes may also be at play.

\section{The Condition of Asia Migratory Bird Affected by Climate Change and Severe Weather- Birdlife Data Zone and IUCN Lists}

The latest data from the Birdlife Data Zone shows that approximately 169 migratory birds in Asia are affected by climate change and severe weather. Of the total, five species $(2.96 \%)$ of migratory birds occupy the critically endangered category in the Global IUCN Red List, namely Siberian Crane (Leucogeranus leucogeranus) from the family Gruidae (Cranes), Christmas Frigatebird (Fregata andrewsi) from the family Fregatidae (Frigatebirds), 
Sociable Lapwing (Vanellus gregarius) from the family Charadriidae (Plovers), Spoonbilled Sandpiper (Calidris pygmaea) from the family Scolopacidae (Sandpipers, Snipes, Phalaropes) and Chinese Crested Tern (Thalasseus bernsteini) from the family Laridae (Gulls, Terns, Skimmers). In addition, there are eight species $(4.73 \%)$ in the endangered category, such as White-headed Duck, Lesser Florican, Barau's Petrel, Abbott's Booby, Great Knot, Far Eastern Curlew, Rufous-headed Robin and Pallas's Fish-eagle. While there are 21 species $(12.43 \%)$ that fall in the vulnerable category, 27 species (15.98\%) are near threatened, and 123 species $(63.91 \%)$ are in the least concerned category (BirdLife International, 2021).

Critically Endangered Species. Referring to Table 2, the Siberian Crane or Siberian White Crane or Snow Crane (Grus leucogeranus) is one of the critically endangered migratory species. According to the IUCN Red List, the Siberian Crane was classified as threatened in 1988, endangered in 1994 and 1996, and critically endangered from 2000 to 2018 (BirdLife International, 2021). According to research by Ming-Qin \& Hong (2014), low water levels in spring and early summer in Lake Poyang have reduced food availability for many water birds that have migrated to the area in recent years. They also discovered that the Siberian Cranes' distribution pattern was impacted by a lack of food availability that could feed all of the cranes in Banghu. Meanwhile, the Siberian Crane's departure time from Lake Poyang was reported as being slower, which might be attributed to a delay in the winter season as a result of climate change. Therefore, it is essential to study and focus on this species in the Poyang lake area, where more than $98 \%$ of their population overwinters in the lake.

Table 2

Asia migratory birds affected by climate change and severe weather (BirdLife International, 2021)

\begin{tabular}{ll}
\hline \multicolumn{1}{c}{ Species } & \multicolumn{1}{c}{ Global (IUCN) status } \\
\hline Leucogeranus leucogeranus & Critically Endangered \\
Fregata andrewsi & Critically Endangered \\
Vanellus gregarius & Critically Endangered \\
Calidris pygmaea & Critically Endangered \\
Thalasseus bernsteini & Critically Endangered \\
Oxyura leucocephala & Endangered \\
Sypheotides indicus & Endangered \\
Pterodroma baraui & Endangered \\
Papasula abbotti & Endangered \\
Numenius madagascariensis & Endangered \\
Calidris tenuirostris & Endangered \\
Haliaeetus leucoryphus & Endangered \\
Larvivora ruficeps & Endangered \\
\hline
\end{tabular}


It has been proven that the Poyang lake area is the most important wintering ground for the globally critically endangered Siberian crane (Chen et al., 2016). In 2011-2012, the total population of Siberian Cranes in the Poyang Lake basin was projected to be 3,500-4,000 individuals. In December 2011, there were 4577 Siberian Cranes (Grus leucogeranus), 302 Hooded Cranes (Grus monacha), 885 White-naped Cranes (Grus vipio), and 8408 Eurasian Cranes (G. grus). In February 2012, there were 3335 Siberian Cranes, 110 (Hooded Cranes), 283 (White-naped Cranes), and 2205 (Eurasian Cranes). Thus, the number of Siberian Cranes counted had fallen by 1242 in February 2012. Similarly, Hooded Cranes declined by 192, White-naped Cranes (602) and Eurasian Cranes (6203) (Li et al., 2012).

The effective population size for Christmas Island frigatebirds (Fregata andrewsi) is around 5,000 (Morris-Pocock et al., 2012), and this species is listed as Critically Endangered by the IUCN (Birdlife International, 2021). For a long time, the status of the Christmas Island Frigatebird in India was unclear until Praveen et al. (2013) discovered few previous reports of Great or Lesser Frigatebird misidentification. It indicates a flaw in earlier researchers' documentation, which resulted in a paucity of data for this bird species. The first record of Christmas Island Frigatebird Fregata Andrewsi in Timor was in 1986, which was found flying along the coast near Kupang, Timor (McKean, 2011). Fregata andrewsi has also been discovered in southern New Guinea (Simpson, 1990). In July 2012, there were 209 individuals of this species in Indonesia. In contrast, in May 2013, 113 individuals of this species were discovered using the Jakarta Bay to obtain food, relax in Sero, and Pulau Rambut at night (Tirtaningtyas \& Yordan, 2017). McMaster et al. (2015) in 2014 found an adult female Christmas Frigatebird and an unconfirmed juvenile Christmas Frigatebird in the Nightcliff foreshore, Darwin, Australia.

Several anthropogenic threats to Christmas Island Frigatebirds have been identified in Jakarta Bay, Indonesia, including the unintentional involvement of fishing gear, as well as capture, poisoning, and shooting (Tirtaningtyas \& Hennicke, 2015). It has also been revealed that climate change can impact the population of this species, with severe storms likely to cause fatality in juveniles and adults (Hill et al., 2004). The situation is anticipated to deteriorate if severe storms become more common as a result of climate change (Harley et al., 2006). This catastrophic storm occurrence will almost certainly increase storm-related fatalities of this species. In addition, higher sea surface temperatures linked with climate change have been shown to impact marine productivity (Harley et al., 2006), which is thought to affect food availability for Christmas Island frigatebirds.

According to Watson et al. (2006), the Sociable Lapwing Vanellus gregarius is a critically endangered species likely to experience a decline in its total population, i.e. from 5000 pairs to 500 pairs, within 11 years. The decline of this species is likely due to climatic and societal changes that cause nesting habitat for the Sociable Lapwing Vanellus gregarius to be more extensively grazed (Shevchenko, 1998). In 1988 this species was 
listed as threatened, vulnerable from 1994 to 2000, and critically endangered from 2004 to 2018 (BirdLife International, 2021). The number of nests of Sociable Lapwing Vanellus gregarius discovered in the 14 core colonies of the Korgalzhyn region, in the other colonies of the Korgalzhyn region, and in the other colonies of the Pavlodar region increased from 2005 to 2007, but then declined from 2008 to 2012. The 330 Sociable Lapwing Vanellus gregarius nests discovered in 2007 were reduced to 137 in 2008, 122 in 2009, 131 in 2010, 105 in 2011, and 44 in 2012 (Sheldon et al., 2012). Watson et al. (2006) expressed worry about the increasingly dry climate in breeding and wintering ranges, which might endanger semi-desert species. The drier climate in its breeding and wintering areas may influence this species, although it is uncertain whether this benefits or harms this semi-desert species (Watson et al., 2006). So, additional research on the link between climate, breeding size, and population size for this species is required. However, contrary to the findings of Jayendra et al. (2014), low rainfall attracts more birds to winter in Gujarat.

Since 1977 and 2000, the breeding population of the critically endangered Spoonbilled Sandpiper Calidris pygmaeus has declined dramatically (Tomkovich et al., 2002). The decrease has indeed continued, with the rate of decline estimated to be $25 \%$ per year (Zöckler et al., 2010a; Zöckler et al., 2010b). This species has declined rapidly throughout the winter range from 2005 to 2013 with current estimates putting the breeding population at less than 120 pairs (242 to 378 individuals) (Zöckler et al., 2016). At the same time, Clark et al. (2018) estimated the spoon-billed sandpiper breeding population in 2014 to be 210 to 288 pairs, with a total post-breeding population of 661 to 718 individuals. Waterbird surveys in early 2018 yielded no Spoon-billed Sandpiper sightings throughout a 243.8 kilometre stretch of coast in North Sumatra Province, from Langkat District to Asahan District (Putra \& Hikmatullah, 2018). Meanwhile, one Spoon-billed Sandpiper was discovered at the end of 2018 (2-4 November) in Seunodon Sub-district, North Aceh District, Aceh Province, Sumatra, Indonesia. It demonstrates that the Spoon-billed Sandpiper is highly endangered and has lacked protection status in Indonesia (Putra et al., 2019). The spoon-billed sandpiper population in China has declined from 2,000 to 2,800 breeding pairs in the 1970s to around 220 in 2010 (Yang et al., 2017). In 1988 this species was listed as threatened, vulnerable from 1994 to 2000, endangered in 2004 and critically endangered from 2008 to 2018 (BirdLife International, 2021). Climate change in their breeding locations has produced soil moisture and vegetation changes in breeding grounds (Tomkovich et al., 2002; Zöckler et al., 2003). This species' population is declining due to hunting and loss of appropriate habitat in trail and winter locations, as well as disturbance, pollution, and the impacts of climate change (Clark et al., 2018; Syroechkovskiy et al., 2010; Tomkovich et al., 2002; Zöckler et al., 2016).

The Chinese Crested Tern Thalasseus bernsteini has less than 50 individuals (Chen et al., 2015) and is the most critically endangered seabird species in Asia (Hung et al., 
2018). This species is not just one of Asia's most endangered species, but it is also one of the world's most endangered seabird species, with only a small breeding population of approximately 100 individuals (Gu et al., 2021; Lu et al., 2020). In their study, Lu et al. (2020) discovered a worldwide population of this species that exceeded 100 for the first time in history, with breeding grounds restricted to East China and the Yellow Seas. In 1988 this species was listed as threatened and critically endangered from 1994 to 2018 (BirdLife International, 2021). It is unclear which causes, such as habitat loss, overexploitation, marine pollution, egg harvesting, climate change, restricted biological niches, or even inherent rarity, are causing the reduction in the population of Chinese Crested Tern species (Brook et al., 2008; Chen et al., 2009; Davies et al., 2004; Liu et al., 2009). Another major factor that may contribute to the near extinction of the endangered Chinese Crested Tern is poachers in the market selling seagull eggs and terns during the breeding season (Chen et al., 2015). Additionally, natural calamities pose a threat to the population of this species since summer hurricanes in coastal areas frequently cause Chinese Crested Tern breeding failure (Chen et al., 2015).

Endangered Species. In 1988, White-headed Duck (Oxyura leucocephala) was listed as threatened, Vulnerable in 1994 \& 1996, and endangered from 2000 to 2017 (BirdLife International, 2021). At the turn of the 21 st century, the global population of the Whiteheaded Duck was estimated to be approximately 8,000 to 13,000 individuals (Li et al., 2003). In 2016, more than 20000 individuals were recorded, while in 2017, around 7500 individuals (Koshkina et al., 2019). In Turkey, the breeding population of the White-headed Duck was estimated to be 200 to 250 pairs from 1996 to 2001, but current observations suggest that the number of such species presently does not surpass 80 to 125 pairs, representing a $50 \%$ drop in two decades. Meanwhile, the non-breeding winter population ranges from 8,500 to 10,000 individuals, with Burdur Lake once housing more than $90 \%$ of the population but no longer serving as a prominent resting site. From more than 10,000 birds in the early 1990s to a few hundred in the early 2000s, this number began to fall (Gürsoy-Ergen, 2019). In addition, climate change has caused the wetlands that once housed White-headed Ducks to dry up in 2018 and 2019. White-headed Ducks, for example, are among the species most impacted when wetlands in Çavuşlu ponds or parts of Lake Mogan, Turkey, begin to dry up early as a result of climate change (Özgencil \& Uslu, 2021).

For at least 50 to 60 years, Lesser Florican Sypheotides indicus has been declining. From 1982 to 1989, its population declined by approximately $60 \%$, but by 1994, it had recovered by $32 \%$ to 2,206 individuals (Kasambe \& Gahale, 2010). Raghavendra (2011) found the first record of the Lesser Florican Sypheotides indicus female at dry Lake Bed, Hesarghatta, Bangalore in 2011; and this species is an endangered endemic group in the Indian subcontinent. India is said to have $90 \%$ of the world's population of the Lesser 
Florican and therefore plays an important role in its protection and conservation (Sankaran et al., 1992). Dutta et al. (2018) stated that threats to this species include the presence of unpredictable and changing rainfall patterns as a result of climate change. Perhaps the consequences of climate change are unproven but probable to happen in the future. The evidence in Dutta et al. (2018) indicates that the lesser florican will become extinct in the world within the next 20 years, and conservation is needed to protect this species. Apte et al. (2020) also argue that the impacts of climate change, particularly erratic rainfall, pose an indirect risk to this species. This Lesser Florican is a monsoon breeder. It changes its breeding sites depending on the monsoon conditions, making conservation challenging. Climate changes and unpredictable rainfall in several areas of its distribution range have resulted in its extinction, or irregular presence in typically frequented sites.

Barau's petrel (Pterodroma baraui) is an endangered tropical seabird (Pinet et al., 2011). The Barau's petrel is an endemic species on Reunion Island that has been listed as endangered by IUCN since 2008, and its population is believed to be declining (Dufour et al., 2016). According to Pinet et al. (2009), the extinction of the Barau petrel happened in less than 100 years owing to the unavailability of cat predation control in this species' temporary breeding colonies. Meanwhile, Le Corre et al. (2002) reported that metropolitan illumination has resulted in large and seasonal light-induced mortality of Barau's petrel fledglings. According to Le Corre et al. (2002), projections concerning population decrease were erroneous due to a lack of precise data on this species' life history. One study shows, because the Petrel Barau species is endemic and strongly philopathic the existing Petrel Barau winter habitat may become less suitable in the future (Pinet et al., 2009). According to Legrand et al. (2016), a large number of Barau petals may have difficulties altering their migratory routes and tactics in a fast-changing world (including climate change). Furthermore, most Intergovernmental Panel on Climate Change (IPCC) models predict that appropriate habitat size will be reduced by the end of the twenty-first century.

Then, the winter area's carrying capacity is diminished, which might lead to increased intra and inter-specific competition for prey. Legrand et al. (2016) undertook one of the first studies to utilise current detection data and habitat modelling to anticipate the long-term impacts of climate change on seabirds (Petrel Barau). Figure 5a depicts how climate change scenarios RCP 2.6, RCP 4.5, and RCP 8.5 forecast a 33\%, 19\%, and 5\% decline in suitable habitat size, respectively. Figure $5 \mathrm{~b}$ depicts all of the scenarios indicating the westward shift, including $\mathrm{RCP} 2.6\left(5^{\circ}\right), \mathrm{RCP} 4.5\left(7^{\circ}\right)$, RCP $6.0\left(11^{\circ}\right)$, and RCP $8.5\left(9^{\circ}\right)$. Meanwhile, RCP $4.5, \mathrm{RCP} 6.0$, and RCP 8.5 forecast a $3^{\circ}, 5^{\circ}$, and $7^{\circ}$ southerly shift, respectively (Figure $5 \mathrm{c}$ ). Based on the graph in Figure 5c, the most optimistic climatic scenario is (RCP 2.6), which anticipated a $2^{\circ}$ northward shift until 2020, followed by stagnation until 2100 . Based on this data, Legrand et al. (2016) determined that suitable habitats are expected to decline and move westward and southward by the end of the twenty-first century. 


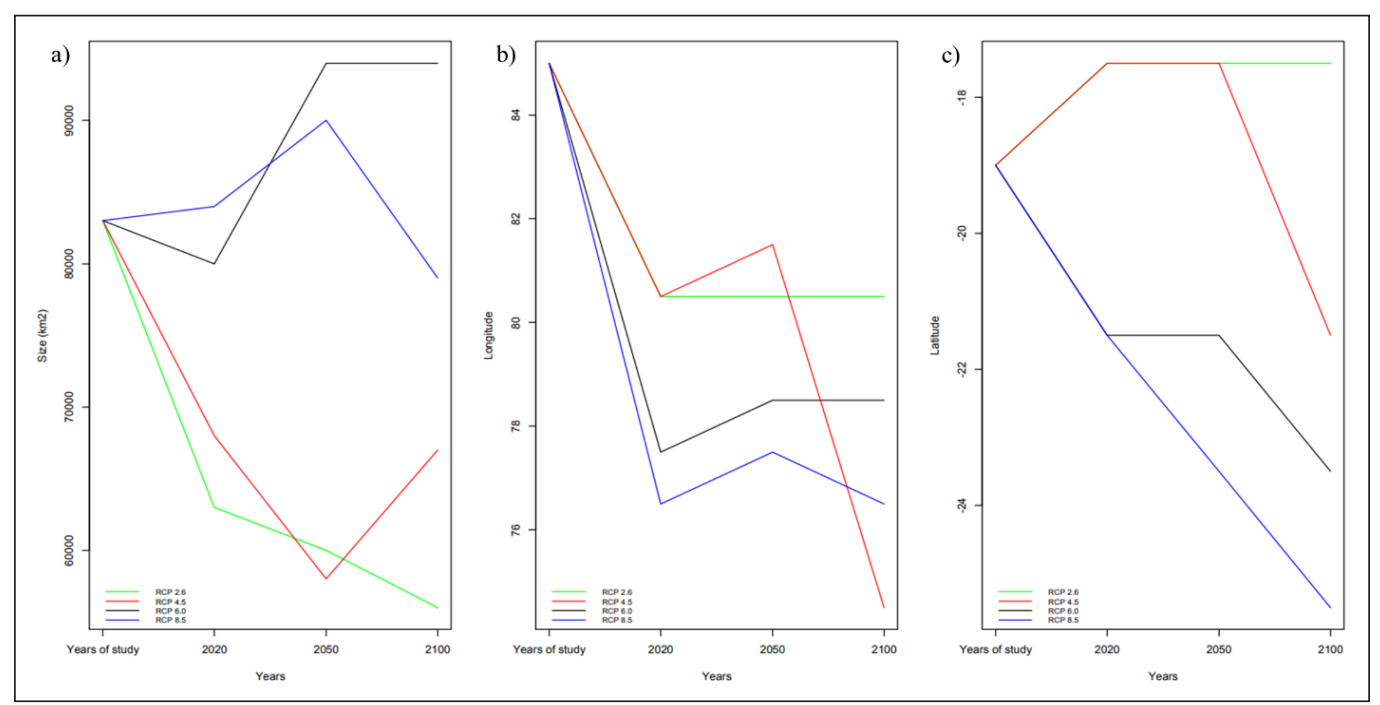

Figure 5. The evolution through time of (a) the size, (b) longitude, and (c) latitude of suitable wintering areas for Barau's petrels under climate change scenarios; Representative Concentration Pathway (RCP 2.6, RCP 4.5, RCP 6.0, RCP 8.5) (Legrand et al., 2016)

Records suggest that between 1970 and 1983, at least 400 couples of Abbott's Booby vanished from the reproductive population (Yorkston \& Green, 1997). In 1988 this species was listed as threatened, Vulnerable in 1994 \& 1996, critically endangered in 2000 and 2004. Then this species came back out of the critical situation from critically endangered to endangered from 2005 to 2019 (BirdLife International, 2021). Christmas Island was the only breeding colony location of Abbott's Booby until 1991, with an estimated population of 2,500 pairs (Yorkston \& Green, 1997). Now, the effective population size for Abbott's Booby is likewise approximately 2,100 individuals on Christmas Island (MorrisPocock et al., 2012). Rising sea surface temperatures (due to anthropogenic greenhouse gas emissions), stochastic events (storms and hurricanes), and global warming are all potential threats to Abbott's boobb (Department of the Environment and Heritage, 2004). This situation likely will cause declination in the population. In addition, climate change, especially rising sea surface temperatures, has reduced marine productivity in Abbott's Boobies foraging near Christmas Island. As a result, it may be claimed that climate change is already impacting the seabird food chain in the Christmas Frigatebird nesting region (Hennicke \& Weimerskirch, 2014).

In 1988, the Far Eastern Curlew (Numenius madagascariensis) was listed as lower risk/ least concern, lower risk/near threatened in 1994 \& 2000, least concern in 2004 to 2009 , vulnerable in 2010 \& 2012 and endangered in 2015 \& 2016 (BirdLife International, 2021). In 1992 and 2008, the Far Eastern Curlew was reported to decline steadily in Australia, at $2.4 \%$ each year in Moreton Bay (Wilson et al., 2011). Meanwhile, in Tasmania since 
the 1950 s, this species has declined by more than $65 \%$ (Reid \& Park, 2003). Hunting, pollution, changes in water regimes, disturbances, and the influence of climate change on breeding sites all pose threats to the species (Harding et al., 2007). In Australia, the species was recently classified as endangered under Australian Government law because of its ongoing population reduction due to its breeding grounds. Decreases in the species have been documented from almost every place monitored along the Australian coast, and local extinction is projected in certain areas over the next thirty years (Lilleyman et al., 2016).

Nearly 425,000 Great Knot individuals are currently known to exist (Hansen et al., 2016). However, the research done by Rogers et al. (2006) and Clemens et al. (2016) revealed that the species' total population in Australia has declined since it was found that this species may have had a greater total population a few decades ago. The same total population loss of $1.8 \%$ each year was seen across the continent (Clemens et al., 2016). Since 2015 and 2016, this species has been categorised by the IUCN as an endangered species (Bird Life International, 2021). According to Piersma et al. (2016), survival during the migration and breeding seasons of red knot Calidris canutus piersmai, great knot Calidris tenuirostris, and bar-tailed godwit Limosa lapponica menzbieri began to fall in 2011. According to them, the three species will suffer an annual loss of 20\%. By 2012, actual survival for the bar-tailed godwit was as low as $0.71,0.68$ for the great knot, and 0.67 for the red knot. According to Clemens et al. (2016), the reduction in migratory shorebird populations (including the Great Knot) along the East Asian - Australasian Flyway (EAAF) was most probably triggered by factors outside of Australia. There is also has a strong relationship between the decrease bird species that use wetlands on the land continent and unsuitable water levels, a hazard that tends to rise with climate change (Finlayson, 2013).

In 1988 Pallas's Fish Eagle (Haliaeetus leucoryphus) was listed as threatened, Vulnerable in 1994 to 2016, and critically endangered from 2017 and 2018 (BirdLife International, 2021). In addition, several migratory bird species and subspecies have been identified as endangered in China, including Long-Tailed Duck (Clangula hyemalis), BlackWinged Kite (Elanus caeruleus vociferus), Pallas's Fish Eagle (Haliaeetus leucoryphus), Himalayan Griffon (Gyps himalayensis), Demoiselle Crane (Anthropoides virgo), WhiteBreasted Waterhen (Amaurornis phoenicurus phoenicurus), Eurasian Collared Dove (Streptopelia decaocto decaocto, Streptopelia decaocto xanthocycla), Chestnut-Winged Cuckoo (Clamator coromandus), Barn Owl (Tyto alba javanica, Tyto alba stertens), and Light-Vented Bulbul (Pycnonotus sinensis sinensis, Pycnonotus sinensis formosae, Pycnonotus sinensis hainanus) (Wu \& Shi, 2016). According to them, the species or subspecies is categorised as endangered as a consequence of climate change, as evidenced by changes in the distribution centre's latitude and longitude, as well as the southern, northwestern, and eastern boundaries of migrating birds (Wu \& Shi, 2016). Pallas's Fish Eagle populations also reported decreased in Bangladesh, and it is now seldom seen outside of the haors (Sourav et al., 2011). 
While field surveys conducted between 2013 and 2016, as well as data from earlier observers in Rajiv Gandhi Orang National Park, India, suggest that Pallas's Fish-eagle is one of the five endangered species (Chakdar et al., 2019). Comprehensive research was conducted in the Bundelkhand region of India between 2006 and 2010. Haliaeetus leucoryphus, Ichthyophaga ichthyaetus, Aquila helica, Ictinaetus malayensis, and Aquila chrysaetos were determined as migratory species to be the rarest in Panna National Park (Gupta \& Kanaujia, 2012). Based on a study done by Gupta and Kanaujia (2012), climatic conditions are one of the greatest risks to eagles in the Bundelkhand Province. Extreme temperatures define the Bundelkhand area, with temperatures ranging from mid to over $40^{\circ} \mathrm{C}$ in the summer and as low as $1^{\circ} \mathrm{C}$ in the winter. As a result, there are documented deaths over the summer. It was also discovered that Haliaeetus leucoryphus in Mongolia is small, and there is evidence of decreasing occupancy. The fall in the population of these species might also be attributed to a long-term decline in accessible surface water, which has resulted in lower water levels in many lakes and the drying up of several major rivers drains for Haliaeetus leucoryphus in Mongolia (Sternberg, 2008; Sukh, 2011). Long-term climate models suggest that this trend will likely continue, potentially leading to habitat loss for this species in the future (Simonov \& Dahmer, 2008).

The Rufous-headed Robin Larvivora ruficeps is one of the world's rarest and leaststudied birds. For the first time in many years, no singing males of Larvivora ruficeps were recorded at Jiuzhaigou, China, in 2016 (Zhao et al., 2016). Rufous-headed Robin Luscinia ruficeps is only known to breed in the Min Shan region of northern Sichuan province and the Qinling Shan range in southern Shaanxi province of China but has not been observed in the latter since 1905. On November 16, 2012, a brown-coloured Luscinia was discovered in an urban garden in central Phnom Penh, Cambodia, the second record outside its breeding range (Mahood et al., 2013). There is very little information on this species' population, although it is likely to exist at very high densities in suitable habitats; nevertheless, a dearth of records implies that it may be relatively limited in distribution and may have a tiny population (Mackinnon, 2001). However, this species was classified as endangered on the IUCN list in 2013 and 2016 and as a migratory bird threatened by climate change (BirdLife International, 2021) No research has been conducted to demonstrate a link between these species and climate change effects. It is most likely owing to the scarcity of data on the population and existence of this species.

\section{CONCLUSION}

Migratory birds are particularly vulnerable to environmental changes such as climate change because they are susceptible to ongoing changes that may be adversely correlated. Conservation measures for maintaining the survival of migratory bird populations are crucial as they are key to good ecosystem health (Bauer \& Hoye, 2014). Relevant parties 
and world leaders need to be more sensitive to climate change that has disrupted the lives of these migratory birds to ensure that they do not become extinct. Based on the literature review results, researchers can conclude that migratory birds are currently stressed by environmental changes, especially climate change that has changed the temperature of the earth's surface. Therefore, it is important to understand how these migratory bird species adapt to ongoing climate change and its impact on the bird itself.

\section{ACKNOWLEDGEMENT}

This research was financed by Short Term Grant (USM) and got cooperation from the Department of Wildlife and National Parks Peninsular Malaysia regarding information and data needed.

\section{REFERENCES}

Ahas, R., \& Aasa, A. (2006). The effects of climate change on the phenology of selected Estonian plant, bird and fish populations. International Journal of Biometeorology, 51(1), 17-26. https://doi.org/10.1007/ s00484-006-0041-z

Alonso, J. C., Palacín, C., Alonso, J. A., \& Martín, C. A. (2009). Post-breeding migration in male great bustards: Low tolerance of the heaviest Palaearctic bird to summer heat. Behavioral Ecology and Sociobiology, 63(12), 1705-1715. https://doi.org/10.1007/s00265-009-0783-9

Apte, D., Narwade, S., Bora, N., Pansare, P., Prajapat, C., Hinonia, V. K., Panwar, A. S., Sahu, H., Mathur, P., \& Rathore, R. S. (2020). Status survey of Lesser Florican Sypheotides indicus for developing a conservation plan for Shokaliya landscape, Ajmer, Rajasthan (Final Report). BNHS.

Bateman, B. L., Pidgeon, A. M., Radeloff, V. C., VanDerWal, J., Thogmartin, W. E., Vavrus, S. J., \& Heglund, P. J. (2015). The pace of past climate change vs. potential bird distributions and land use in the United States. Global Change Biology, 22(3), 1130-1144. https://doi.org/10.1111/gcb.13154

Bauer, S., \& Hoye, B. J. (2014). Migratory animals couple biodiversity and ecosystem functioning worldwide. Science, 344(6179), Article 1242552. https://doi.org/10.1126/science.1242552

BirdLife International. (2021). Introducing the IUCN red list. BirdLife.

Both, C., \& te Marvelde, L. (2007). Climate change and timing of avian breeding and migration throughout Europe. Climate Research, 35(1-2), 93-105. https://doi.org/10.3354/cr00716

Both, C., Bouwhuis, S., Lessells, C. M., \& Visser, M. E. (2006). Climate change and population declines in a long-distance migratory bird. Nature, 441(7089), 81-83. https://doi.org/10.1038/nature04539

Bridge, L. K., Stroud, D., Galbraith, C. A., \& Boere, G. (2007). Waterbirds around the world: A global overview of the conservation, management and research of the world's waterbird flyways. The Stationary Office Books.

Briedis, M., Hahn, S., \& Adamík, P. (2017). Cold spell en route delays spring arrival and decreases apparent survival in a long-distance migratory songbird. BMC Ecology, 17(1), 1-8. https://doi.org/10.1186/s12898017-0121-4 
Brook, B. W., Sodhi, N. S., \& Bradshaw, C. J. (2008). Synergies among extinction drivers under global change. Trends in Ecology \& Evolution, 23(8), 453-460. https://doi.org/10.1016/j.tree.2008.03.011

Burgess, M. D., Smith, K. W., Evans, K. L., Leech, D., Pearce-Higgins, J. W., Branston, C. J., Briggs, K., Clark, J. R., du Feu, C. R., Lewthwaite, K., Nager, R. G., Sheldon, B. C., Smith, J. A., Whytock, R. C., Willis, S. G., \& Phillimore, A. B. (2018). Tritrophic phenological match-mismatch in space and time. Nature Ecology \& Evolution, 2(6), 970-975. https://doi.org/10.1038/s41559-018-0543-1

Chakdar, B., Singha, H., \& Choudhury, M. R. (2019). Bird community of Rajiv Gandhi Orang National Park, Assam. Journal of Asia-Pacific Biodiversity, 12(4), 498-507. https://doi.org/10.1016/j.japb.2019.07.003

Chen, B., Cui, P., Xu, H., Lu, X., Lei, J., Wu, Y., Shao, M., Ding, H., Wu, J., Cao, M., \& Liu, G. (2016). Assessing the suitability of habitat for wintering Siberian cranes (Leucogeranus leucogeranus) at different water levels in Poyang Lake area, China. Polish Journal of Ecology, 64(1), 84-97. https://doi.org/10.31 61/15052249PJE2016.64.1.008

Chen, S., Chang, S. H., Liu, Y., Chan, S., Fan, Z., Chen, C., Yen, C. W., \& Guo, D. (2009). A small population and severe threats: Status of the critically endangered Chinese crested tern Sterna bernsteini. Oryx, 43(2), 209-212. https://doi.org/10.1017/S0030605308001142

Chen, S., Fan, Z., Roby, D. D., Lu, Y., Chen, C., Huang, Q., Cheng, L., \& Zhu, J. (2015). Human harvest, climate change and their synergistic effects drove the Chinese crested tern to the brink of extinction. Global Ecology and Conservation, 4, 137-145. https://doi.org/10.1016/j.gecco.2015.06.006

Clark, N. A., Anderson, G. Q. A., Li, J., Syroechkovskiy, E. E., Tomkovich, P. S., Zöckler, C., Lee, R., \& Green, R. E. (2018). First formal estimate of the world population of the critically endangered spoonbilled sandpiper Calidris pygmaea. Oryx, 52(1), 137-146. https://doi.org/10.1017/S0030605316000806

Clemens, R., Rogers, D. I., Hansen, B. D., Gosbell, K., Minton, C. D. T., Straw, P., Bamford, M., Woehler, E. J., Milton, D. A., Weston, M. A., Venables, B., Wellet, D., Rutherford, B., Onton, K., Herrod, A., Studds, C. E., Choi, C. Y., Dhanjal-Adams, K. L., Murray, N. J., ... \& Fuller, R. A. (2016). Continental-scale decreases in shorebird populations in Australia. Emu-Austral Ornithology, 116(2), 119-135. https://doi. org/10.1071/MU15056

Collins, M., Knutti, R., Arblaster, J., Dufresne, J. L., Fichefet, T., Friedlingstein, P., Gao, X., Gutowski, W. J., Johns, T., Krinner, G., Shongwe, M., Tebaldi, C., Weaver, A. J., Wehner, M. F., Allen, M. R., Andrews, T., Beyerle, U., Bitz, C. M., Bony, S., \& Booth, B. B. B. (2013). Long-term climate change: Projections, commitments and irreversibility. In Climate Change 2013-The Physical Science Basis: Contribution of Working Group I to the Fifth Assessment Report of the Intergovernmental Panel on Climate Change (pp. 1029-1136). Cambridge University Press.

Davies, K. F., Margules, C. R., \& Lawrence, J. F. (2004). A synergistic effect puts rare, specialized species at greater risk of extinction. Ecology, 85(1), 265-271. https://doi.org/10.1890/03-0110

Department of the Environment and Heritage. (2004). National recovery plan for the Abbott's Booby (Papasula abbotti). Department of the Environment and Heritage

Dufour, O., Gineste, B., Bas, Y., Le Corre, M., \& Artières, T. (2016). First automatic passive acoustic tool for monitoring two species of procellarides (Pterodroma baraui and Puffinus bailloni) on Reunion Island, Indian Ocean. Ecological Informatics, 35, 55-60. https://doi.org/10.1016/j.ecoinf.2016.08.004 
Dunn, P. O., \& Møller, A. P. (2013). Changes in breeding phenology and population size of birds. Journal of Animal Ecology, 83(3), 729-739. https://doi.org/10.1111/1365-2656.12162

Dutta, S., Narwade, S., Bipin, C. M., Gadhavi, D., Uddin, M., Mhaskar, M., Pandey, D., Mohan, A., Sharma, H., Iyer, S., Tripathi, R., Verma, V., Varma, V., Jangid, A., Chakdar, B., Karulkar, A., Lambture, B., Khongsai, N., Kumar, S., ... \& Jhala, Y. V. (2018). Status of the lesser florican Sypheotides indicus and implications for its conservation. Wildlife Institute of India.

Faaborg, J., Holmes, R. T., Anders, A. D., Bildstein, K. L., Dugger, K. M., Gauthreaux, S. A., Heglund, P., Hobson, K. A., Jahn, A. E., Johnson, D. H., Latta, S. C., Levey, D. J., Marra, P. P., Merkord, C. L., Nol, E., Rothstein, S. I., Sherry, T. W., Sillett, T. S., Thompson, F. R., \& Warnock, N. (2010). Recent advances in understanding migration systems of New World land birds. Ecological Monographs, 80(1), 3-48. https:// doi.org/10.1890/09-0395.1

Finlayson, C. M. (2013). Climate change and the wise use of wetlands: Information from Australian wetlands. Hydrobiologia, 708(1), 145-152. https://doi.org/10.1007/s10750-013-1474-0

Franks, S. E., Pearce-Higgins, J. W., Atkinson, S., Bell, J. R., Botham, M. S., Brereton, T. M., Harrington, R., $\&$ Leech, D. I. (2017). The sensitivity of breeding songbirds to changes in seasonal timing is linked to population change but cannot be directly attributed to the effects of trophic asynchrony on productivity. Global Change Biology, 24(3), 957-971. https://doi.org/10.1111/gcb.13960

Galbraith, C., Jones, T., Kirby, J., \& Mundkur, T. (2014). A review of migratory bird flyways and priorities for management (CMS Technical Series Publication No. 27). Secretariat of the Convention on the Conservation of Migratory Species of Wild Animals.

Gilroy, J. J., Gill, J. A., Butchart, S. H. M., Jones, V. R., \& Franco, A. M. A. (2016). Migratory diversity predicts population declines in birds. Ecology Letters, 19(3), 308-317. https://doi.org/10.1111/ele.12569

Gu, N., Chen, G., Yang, J., Zheng, C., Gao, X., Yuan, L., Wang, S., Fan, Z., Lu, Y., Song, G., Chen, S., \& Liu, Y. (2021). Novel microsatellite markers reveal low genetic diversity and evidence of heterospecific introgression in the critically endangered Chinese crested tern (Thalasseus bernsteini). Global Ecology and Conservation, 28, Article e01629. https://doi.org/10.1016/j.gecco.2021.e01629

Gupta, R., \& Kanaujia, A. (2012). Ecology of eagles in Bundelkhand Region, India. Veterinary World, 5(1), 31-35. https://doi.org/10.5455/vetworld.2012.31-35

Gürsoy-Ergen, A. (2019). Hope for the white-headed duck, Oxyura leucocephala (Aves: Anatidae) in Turkey despite a declining breeding population and abandonment of its traditional wintering area? Zoology in the Middle East, 65(2), 116-127. https://doi.org/10.1080/09397140.2019.1580930

Hansen, B. D., Fuller, R. A., Watkins, D., Rogers, D. I., Clemens, R. S., Newman, M., Woehler, E. J., \& Weller, D. R. (2016). Revision of the East Asian-Australasian Flyway population estimates for 37 listed migratory shorebird species (Unpublished report). Department of the Environment, BirdLife Australia, Melbourne.

Harding, S. B., Wilson, J. R., \& Geering, A. D. W. (2007). Threats to shorebirds and conservation actions. In A. D. W. Geering, L. Agnew, \& S. Harding (Eds.), Shorebirds of Australia (pp. 197-213). CSIRO Pubishing.

Harley, C. D. G., Hughes, A. R., Hultgren, K. M., Miner, B. G., Sorte, C. J. B., Thornber, C. S., Rodriguez, L. F., Tomanek, L., \& Williams, S. L. (2006). The impacts of climate change in coastal marine systems. Ecology letters, 9(2), 228-241. https://doi.org/10.1111/j.1461-0248.2005.00871.x 
Harris, J., Yong, D., Sodhi, N., Subaraj, R., Fordham, D., \& Brook, B. (2013). Changes in autumn arrival of long-distance migratory birds in Southeast Asia. Climate Research, 57(2), 133-141. https://doi.org/10.3354/ cr01172

Hennicke, J. C., \& Weimerskirch, H. (2014). Coping with variable and oligotrophic tropical waters: Foraging behaviour and flexibility of the Abbott's booby Papasula abbotti. Marine Ecology Progress Series, 499, 259-273. https://doi.org/10.3354/meps10664

Hill, R., Dunn, A., \& Australia, B. (2004). National recovery plan for the Christmas Island Frigatebird (Fregata andrewsi). Commonwealth of Australia, Canberra.

Horton, K. G., La Sorte, F. A., Sheldon, D., Lin, T. Y., Winner, K., Bernstein, G., Maji, S., Hochachka, W. M., \& Farnsworth, A. (2020). Phenology of nocturnal avian migration has shifted at the continental scale. Nature Climate Change, 10(1), 63-68. https://doi.org/10.1038/s41558-019-0648-9

Hu, J., Hu, H., \& Jiang, Z. (2010). The impacts of climate change on the wintering distribution of an endangered migratory bird. Oecologia, 164(2), 555-565. https://doi.org/10.1007/s00442-010-1732-z

Hu, R., Wen, C., Gu, Y., Wang, H., Gu, L., Shi, X., Zhong, J., Wei, M., He, F., \& Lu, Z. (2017). A bird's view of new conservation hotspots in China. Biological Conservation, 211, 47-55. https://doi.org/10.1016/j. biocon.2017.03.033

Hughes, L. (2000). Biological consequences of global warming: is the signal already apparent? Trends in Ecology \& Evolution, 15(2), 56-61. https://doi.org/10.1016/s0169-5347(99)01764-4

Hung, C. H., Chang, L. N., Chiang, K. K., \& Yuan, H. W. (2018). Trends in numbers of the critically endangered Chinese crested tern Thalasseus bernsteini and sympatrically nesting greater crested Tern T. bergii in the Matsu archipelago, Taiwan. Bird Conservation International, 29(3), 386-399. https://doi.org/10.1017/ S0959270918000369

Hurlbert, A. H., \& Liang, Z. (2012). Spatiotemporal variation in avian migration phenology: Citizen science reveals effects of climate change. PLoS ONE, 7(2), Article e31662. https://doi.org/10.1371/journal. pone. 0031662

Hutto, R. L. (2000). On the importance of en route period to the conservation of migratory landbirds. Studies in Avian Biology, 20, 109-114. https://sora.unm.edu/node/139385

Jayendra, L., Gavali, D., Deshkar, S., \& Rathod, J. (2014). Migration pattern of sociable lapwing (Vallenus Gregarious) in wintering grounds of Gujarat, India. International Journal of Research in Zoology, 4(2), 29-31.

Jonzen, N. (2006). Rapid advance of spring arrival dates in long-distance migratory birds. Science, 312(5782), 1959-1961. https://doi.org/10.1126/science.1126119

Kamp, J., Oppel, S., Ananin, A. A., Durnev, Y. A., Gashev, S. N., Hölzel, N., Mishchenko, A. L., Pessa, J., Smirenski, S. M., Strelnikov, E. G., Timonen, S., Wolanska, K., \& Chan, S. (2015). Global population collapse in a superabundant migratory bird and illegal trapping in China. Conservation Biology, 29(6), 1684-1694. https://doi.org/10.1111/cobi.12537

Karell, P., Ahola, K., Karstinen, T., Valkama, J., \& Brommer, J. E. (2011). Climate change drives microevolution in a wild bird. Nature Communications, 2(1), 1-7. https://doi.org/10.1038/ncomms 1213 
Kasambe, R., \& Gahale, P. (2010). Status survey and sighting records of Lesser Florican in Maharashtra. Mistnet, 11(2), 7-9.

Kingsolver, J. G., \& Buckley, L. B. (2015). Climate variability slows evolutionary responses of Colias butterflies to recent climate change. Proceedings of the Royal Society B: Biological Sciences, 282(1802), Article 20142470. https://doi.org/10.1098/rspb.2014.2470

Koshkina, A. I., Koshkin, A. V., Timoshenko, A. Y., Koshkin, A. A., \& Schielzeth, H. (2019). A population survey of the endangered white-headed duck Oxyura leucocephala in Kazakhstan shows an apparently increasing Eastern population. Bird Study, 66(1), 111-120. https://doi.org/10.1080/00063657.2019.161 8239

La Sorte, F. A., Fink, D., Blancher, P. J., Rodewald, A. D., Ruiz-Gutierrez, V., Rosenberg, K. V., Hochachka, W. M., Verburg, P. H., \& Kelling, S. (2017). Global change and the distributional dynamics of migratory bird populations wintering in Central America. Global Change Biology, 23(12), 5284-5296. https://doi. org/10.1111/gcb.13794

Langham, G. M., Schuetz, J. G., Distler, T., Soykan, C. U., \& Wilsey, C. (2015). Conservation status of North American birds in the face of future climate change. PloS ONE, 10(9), Article e0135350. https://doi. org/10.1371/journal.pone.0135350

Le Corre, M., Ollivier, A., Ribes, S., \& Jouventin, P. (2002). Light-induced mortality of petrels: A 4-year study from Réunion Island (Indian Ocean). Biological Conservation, 105(1), 93-102. https://doi.org/10.1016/ S0006-3207(01)00207-5

Legrand, B., Benneveau, A., Jaeger, A., Pinet, P., Potin, G., Jaquemet, S., \& Le Corre, M. (2016). Current wintering habitat of an endemic seabird of Réunion Island, Barau's petrel Pterodroma baraui, and predicted changes induced by global warming. Marine Ecology Progress Series, 550, 235-248. https:// doi.org/10.3354/meps 11710

Lehikoinen, E., Sparks, T. H., \& Zalakevicius, M. (2004). Arrival and departure dates. Birds and Climate Change, 35, 1-31. https://doi.org/10.1016/s0065-2504(04)35001-4

Li, D., Wei, Z., \& Mundkur, T. (2003). Status overview and recommendations for conservation of the whiteheaded duck Oxyura leucocephala in Central Asia. Convention on Conservation of Migratory Species of Wild Animals.

Li, F., Wu, J., Harris, J., \& Burnham, J. (2012). Number and distribution of cranes wintering at Poyang Lake, China during 2011-2012. Chinese Birds, 3(3), 180-190. https://doi.org/10.5122/cbirds.2012.0027

Liang, J., Gao, X., Zeng, G., Hua, S., Zhong, M., Li, X., \& Li, X. (2018). Coupling modern portfolio theory and marxan enhances the efficiency of lesser white-fronted goose's (Anser erythropus) habitat conservation. Scientific Reports, 8(1), 1-8. https://doi.org/10.1038/s41598-017-18594-2

Liang, J., Xing, W., Zeng, G., Li, X., Peng, Y., Li, X., Gao, X., \& He, X. (2018). Where will threatened migratory birds go under climate change? Implications for China's national nature reserves. Science of the Total Environment, 645, 1040-1047. https://doi.org/10.1016/j.scitotenv.2018.07.196

Lilleyman, A. M. A. N. D. A., Garnett, S. T., Rogers, D. I., \& Lawes, M. J. (2016). Trends in relative abundance of the Eastern Curlew (Numenius madagascariensis) in Darwin, Northern Territory. Stilt, 68, 25-30. 
Liu, Y., Guo, D. S., Qiao, Y. L., Zhang, E., \& Cai, B. (2009). Regional extirpation of the critically endangered Chinese Crested Tern (Thalasseus bernsteini) from the Shandong coast, China. Waterbirds, 32(4), 597 599. https://doi.org/10.1675/063.032.0414

Lu, Y., Roby, D. D., Fan, Z., Chan, S., Lyons, D. E., Hong, C. H., Wang, S., Yang, J., Zhou, X., Chen, D., Yuan, H. W., \& Chen, S. (2020). Creating a conservation network: Restoration of the critically endangered Chinese crested tern using social attraction. Biological Conservation, 248, Article 108694. https://doi. org/10.1016/j.biocon.2020.108694

Ma, Z., Melville, D. S., Liu, J., Chen, Y., Yang, H., Ren, W., Zhang, Z., Piersma, T., \& Li, B. (2014). Rethinking China's new great wall. Science, 346(6212), 912-914. https://doi.org/10.1126/science.1257258

Mackinnon, J. (2001). Threatened birds of Asia: The BirdLife International Red Data Book. Collar, N.J., (Editorin-chief), Andreev, A.V., Chan, S., Crosby, M.J., Subramanya, S. and Tobias, J.A. Maps by Rudyanto and M. J. Crosby. BirdLife International, Cambridge. 3,038 pages, in two volumes, £55.00. Bird Conservation International, 11(4), 325-328. https://doi.org/10.1017/S0959270901210375

Mahood, S. P., Eaton, J. A., \& Leader, P. J. (2013). Second record of Rufous-headed Robin Luscinia ruficeps outside its breeding range and a description of its first-winter plumage. BirdingAsia, 19, 43-47.

Mayor, S. J., Guralnick, R. P., Tingley, M. W., Otegui, J., Withey, J. C., Elmendorf, S. C., Andrew, M. E., Leyk, S., Pearse, I. S., \& Schneider, D. C. (2017). Increasing phenological asynchrony between spring green-up and arrival of migratory birds. Scientific Reports, 7(1), 1-10. https://doi.org/10.1038/s41598-017-02045-z

McCarty, J. P. (2001). Ecological consequences of recent climate change. Conservation Biology, 15(2), 320331. https://doi.org/10.1046/j.1523-1739.2001.015002320.x

McKean, J. L. (2011). A first record of Christmas Island Frigatebird Fregata andrewsi on Timor. Kukila, 3(1$2), 48$.

McMaster, D., Rayner, T. S., \& McMaster, C. A. (2015). Additional records of Christmas Frigatebird'Fregata andrewsi' in the Northern Territory, Australia. Australian Field Ornithology, 32(3), 113-117.

Menzel, A., Sparks, T. H., Estrella, N., Koch, E., Aasa, A., Ahas, R., Alm-Kübler, K., Bissolli, P., Braslavská, O., Briede, A., Chmielewski, F. M., Crepinsek, Z., Curnel, Y., Dahl, A., Defila, C., Donnelly, A., Filella, Y., Jatczak, K., Måge, F., \& Mestre, A. (2006). European phenological response to climate change matches the warming pattern. Global Change Biology, 12(10), 1969-1976. https://doi.org/10.1111/j.13652486.2006.01193.x

Miller-Rushing, A. J., Høye, T. T., Inouye, D. W., \& Post, E. (2010). The effects of phenological mismatches on demography. Philosophical Transactions of the Royal Society B: Biological Sciences, 365(1555), 3177-3186. https://doi.org/10.1098/rstb.2010.0148

Ming-Qin, S. H. A. O., \& Hong, G. U. O. (2014). Population sizes and group characteristics of Siberian crane (Leucogeranus leucogeranus) and hooded crane (Grus monacha) in Poyang Lake Wetland. Zoological Research, 35(5), 373-379. https://dx.doi.org/10.13918\%2Fj.issn.2095-8137.2014.5.373

Møller, A. P. (2001). Heritability of arrival date in a migratory bird. Proceedings of the Royal Society of London. Series B: Biological Sciences, 268(1463), 203-206. https://doi.org/10.1098/rspb.2000.1351 
Møller, A. P., Rubolini, D., \& Lehikoinen, E. (2008). Populations of migratory bird species that did not show a phenological response to climate change are declining. Proceedings of the National Academy of Sciences, 105(42), 16195-16200.

Morris-Pocock, J. A., Hennicke, J. C., \& Friesen, V. L. (2012). Effects of long-term isolation on genetic variation and within-island population genetic structure in Christmas Island (Indian Ocean) seabirds. Conservation Genetics, 13(6), 1469-1481. https://doi.org/10.1007/s10592-012-0390-6

NOAA National Centers for Environmental Information. (2021). Climate at a Glance: Global Mapping. National Oceanic and Atmospheric Administration.

Nourani, E., Yamaguchi, N. M., \& Higuchi, H. (2017). Climate change alters the optimal wind-dependent flight routes of an avian migrant. Proceedings of the Royal Society B: Biological Sciences, 284(1854), Article 20170149. https://doi.org/10.1098/rspb.2017.0149

Ottersen, G., Planque, B., Belgrano, A., Post, E., Reid, P. C., \& Stenseth, N. C. (2001). Ecological effects of the North Atlantic Oscillation. Oecologia, 128(1), 1-14. https://doi.org/10.1007/s004420100655

Özgencil, İ. K., \& Uslu, A. (2021). Update on the status of white-headed duck Oxyura leucocephala and its breeding phenology in Central Anatolia, Turkey. Sandgrouse, 43, 112-122.

Pachauri, R. K., Allen, M. R., Barros, V. R., Broome, J., Cramer, W., Christ, R., Church, J. A., Clarke, L., Dahe, Q., Dasgupta, P., Dubash, N. K., Edenhofer, O., Elgizouli, I., Field, C. B., Forster, P., Friedlingstein, P., Fuglestvedt, J., Gomez-Echeverri, L., Hallegatte, S., ... \& van Ypserle, J. P. (2014). Climate change 2014: Synthesis Report. Contribution of Working Groups I, II and III to the Fifth Assessment Report of the Intergovernmental Panel on Climate Change. IPCC.

Pacifici, M., Visconti, P., Butchart, S. H. M., Watson, J. E. M., Cassola, F. M., \& Rondinini, C. (2017). Species' traits influenced their response to recent climate change. Nature Climate Change, 7(3), 205-208. https:// doi.org/10.1038/nclimate3223

Piersma, T., Lok, T., Chen, Y., Hassell, C. J., Yang, H. Y., Boyle, A., Slaymaker, M., Chan, Y. C., Melville, D. S., Zhang, Z. W., \& Ma, Z. (2016). Simultaneous declines in summer survival of three shorebird species signals a flyway at risk. Journal of Applied Ecology, 53(2), 479-490. https://doi.org/10.1111/1365-2664.12582

Pinet, P., Jaquemet, S., Pinaud, D., Weimerskirch, H., Phillips, R., \& Le Corre, M. (2011). Migration, wintering distribution and habitat use of an endangered tropical seabird, Barau's petrel Pterodroma baraui. Marine Ecology Progress Series, 423, 291-302. https://doi.org/10.3354/meps08971

Pinet, P., Salamolard, M., Probst, J. M., Russell, J., Jaquemet, S., \& Le Corre, M. (2009). Barau's Petrel Pterodroma baraui: History, biology and conservation of an endangered endemic petrel. Marine Ornithology, 37(2), 107-113.

Praveen, J., Jayapal, R., \& Pittie, A. (2013). Notes on Indian rarities-1: Seabirds. Indian Birds, 8(5), 113-125.

Pulido, F. (2007). Phenotypic changes in spring arrival: Evolution, phenotypic plasticity, effects of weather and condition. Climate Research, 35(1-2), 5-23. https://doi.org/10.3354/cr00711

Putra, C. A., \& Hikmatullah, D. (2018). Survey of waterbird and waterbird hunting problem on the Eastern Coastline of North Sumatra, Indonesia (January-April 2018) (Unpublished report). The Manfred-Hermsen Stiftung Foundation, Birding Sumatra/Sumatra Wild Heritage Foundation, North Sumatra, Indonesia. 
Putra, C. A., Hikmatullah, D., Zöckler, C., Syroechkovskiy, E. E., \& Hughes, B. (2019). Spoon-billed Sandpiper: A new species for Indonesia. Wader Study, 126(1), 60-63. https://doi.org/10.18194/ws.00135

Raghavendra, M. (2011). Occurrence of Lesser Florican sypheotides indicus in Bangalore, Karnataka, India. Indian BIRDS, 7(5), 140-142.

Reid, T., \& Park, P. (2003). Continuing decline of Eastern Curlew, Numenius madagascariensis, in Tasmania. Emu - Austral Ornithology, 103(3), 279-283. https://doi.org/10.1071/mu00079

Richardson, W. J. (1990). Timing of bird migration in relation to weather: Updated review. In E. Gwinner (Ed.), Bird Migration (pp. 78-101). Springer. https://doi.org/10.1007/978-3-642-74542-3_6

Rogers, D. I., Rogers, K. G., Gosbell, K. B., \& Hassell, C. J. (2006). Causes of variation in population monitoring surveys: Insights from non-breeding counts in north-western Australia, 2004-2005. Stilt, 50, 176-193.

Roulin, A. (2014). Melanin-based colour polymorphism responding to climate change. Global Change Biology, 20(11), 3344-3350. https://doi.org/10.1111/gcb.12594

Rubolini, D., Møller, A., Rainio, K., \& Lehikoinen, E. (2007). Intraspecific consistency and geographic variability in temporal trends of spring migration phenology among European bird species. Climate Research, 35(1-2), 135-146. https://doi.org/10.3354/cr00720

Runge, C. A., Watson, J. E. M., Butchart, S. H. M., Hanson, J. O., Possingham, H. P., \& Fuller, R. A. (2015). Protected areas and global conservation of migratory birds. Science, 350(6265), 1255-1258. https://doi. org/10.1126/science.aac9180

Sankaran, R., Rahmani, A. R., \& Ganguli-Lachungpa, U. (1992). The distribution and status of the Lesser Florican Sypheotides indica (JF Miller) in the Indian subcontinent. Journal of the Bombay Natural History Society, 89(2), 156-179.

Santer, B. D., Wehner, M. F., Wigley, T. M. L., Sausen, R., Meehl, G. A., Taylor, K. E., Ammann, C., Arblaster, J., Washington, W. M., Boyle, J. S., \& Brüggemann, W. (2003). Contributions of anthropogenic and natural forcing to recent tropopause height changes. Science, 301(5632), 479-483. https://www.jstor. org/stable/3834678?seq $=1$

Scheffers, B. R., De Meester, L., Bridge, T. C. L., Hoffmann, A. A., Pandolfi, J. M., Corlett, R. T., Butchart, S. H. M., Pearce-Kelly, P., Kovacs, K. M., Dudgeon, D., Pacifici, M., Rondinini, C., Foden, W. B., Martin, T. G., Mora, C., Bickford, D., \& Watson, J. E. M. (2016). The broad footprint of climate change from genes to biomes to people. Science, 354(6313), aaf7671-1-aaf7671-11. https://doi.org/10.1126/science.aaf7671

Sheldon, R. D., Kamp, J., Koshkin, M. A., Urazaliev, R. S., Iskakov, T. K., Field, R. H., Salemgareev, A. R., Khrokov, V. V., Zhuly, V. A., Sklyarenko, S. L., \& Donald, P. F. (2012). Breeding ecology of the globally threatened sociable lapwing Vanellus gregarius and the demographic drivers of recent declines. Journal of Ornithology, 154(2), 501-516. https://doi.org/10.1007/s10336-012-0921-4

Shevchenko, V. L. (1998). The sociable plover Chettusia gregaria north of the Caspian Sea. Bulletin-Wader Study Group, 87, 48-50.

Shuter, J. L., Broderick, A. C., Agnew, D. J., Jonzén, N., Godley, B. J., Milner-Gulland, E. J., \& Thirgood, S. (2011). Conservation and management of migratory species. In E. J. Milner-Gulland, J. M. Fryxell \& A. R. E. Sinclair (Eds.), Animal migration: A synthesis (pp. 172-206). Oxford University Press. 
Sillett, T. S., Holmes, R. T., \& Sherry, T. W. (2000). Impacts of a global climate cycle on population dynamics of a migratory Songbird. Science, 288(5473), 2040-2042. https://doi.org/10.1126/science.288.5473.2040

Simonov, E. A., \& Dahmer, T. D. (Eds.). (2008). Amur-Heilong river basin reader (p. 426). Ecosystems.

Simpson, D. M. (1990). Paradise lost? Birdwatching along the Fly River, Papua New Guinea. Sea Swallow, 39, 53-57.

Solomon, S., Manning, M., Marquis, M., \& Qin, D. (2007). Climate change 2007-the physical science basis: Working group I contribution to the fourth assessment report of the IPCC (Vol. 4). Cambridge University Press.

Sourav, S. H., Ahmed, B. A. S. H. I. R., \& Thompson, P. A. U. L. (2011). Pallas's fish eagle Haliaeetus leucoryphus in Bangladesh. Birding ASIA, 16, 101-105.

Sternberg, T. (2008). Environmental challenges in Mongolia's dryland pastoral landscape. Journal of Arid Environments, 72(7), 1294-1304. https://doi.org/10.1016/j.jaridenv.2007.12.016

Sukh, T. (2011). Local understanding of hydro-climate changes in Mongolia (MSc Thesis). Colorado State University, USA.

Syroechkovski, E. E., Tomkovich, P. S., Kashiwagi, M., Taldenkov, I. A., Buzin, V. A., Lappo, E. G., \& Zöckler, C. (2010). Population decline in the spoon-billed sandpiper (Eurynorhynchus pygmeus) in northern Chukotka based on monitoring on breeding grounds. Biology Bulletin, 37(9), 941-951. https:// doi.org/10.1134/s1062359010090074

Tirtaningtyas, F. N., \& Hennicke, J. C. (2015). Threats to the critically endangered Christmas Island Frigatebird Fregata andrewsi in Jakarta Bay, Indonesia, and implications for reconsidering conservation priorities. Marine Ornithology, 43, 137-140.

Tirtaningtyas, F. N., \& Yordan, K. (2017). Updating the seabird fauna of Jakarta Bay, Indonesia. Marine Ornithology, 45, 11-16.

Tomkovich, P. S., Syroechkovski Jr, E. E., Lappo, E. G., \& Zöckler, C. (2002). First indications of a sharp population decline in the globally threatened Spoon-billed Sandpiper Eurynorhynchus pygmeus. Bird Conservation International, 12(1), 1-18. https://doi.org/10.1017/s0959270902002010

Trouwborst, A. (2012). Transboundary wildlife conservation in a changing climate: Adaptation of the Bonn convention on migratory species and its daughter instruments to climate change. Diversity, 4(3), 258-300. https://doi.org/10.3390/d4030258

Turrin, C. O. U. R. T. N. E. Y., \& Watts, B. D. (2016). Sustainable mortality limits for migratory shorebird populations within the East Asian-Australian Flyway. Stilt, 68, 2-17.

Walther, G. R., Post, E., Convey, P., Menzel, A., Parmesan, C., Beebee, T. J. C., Fromentin, J. M., HoeghGuldberg, O., \& Bairlein, F. (2002). Ecological responses to recent climate change. Nature, 416(6879), 389-395. https://doi.org/10.1038/416389a

Warren, R., VanDerWal, J., Price, J., Welbergen, J. A., Atkinson, I., Ramirez-Villegas, J., Osborn, T. J., Jarvis, A., Shoo, L. P., Williams, S. E., \& Lowe, J. (2013). Quantifying the benefit of early climate change mitigation in avoiding biodiversity loss. Nature Climate Change, 3(7), 678-682. https://doi.org/10.1038/nclimate1887 
Watson, M., Wilson, J. M., Koshkin, M., Sherbakov, B., Karpov, F., Gavrilov, A., Schielzeth, H., Brombacher, M., Collar, N. J., \& Cresswell, W. (2006). Nest survival and productivity of the critically endangered sociable lapwing Vanellus gregarius. Ibis, 148(3), 489-502. https://doi.org/10.1111/j.1474-919x.2006.00555.x

Wauchope, H. S., Shaw, J. D., Varpe, Ø., Lappo, E. G., Boertmann, D., Lanctot, R. B., \& Fuller, R. A. (2017). Rapid climate-driven loss of breeding habitat for Arctic migratory birds. Global Change Biology, 23(3), 1085-1094. https://doi.org/10.1111/gcb.13404

Weeks, B. C., Willard, D. E., Zimova, M., Ellis, A. A., Witynski, M. L., Hennen, M., \& Winger, B. M. (2019). Shared morphological consequences of global warming in North American migratory birds. Ecology Letters, 23(2), 316-325. https://doi.org/10.1111/ele.13434

Wilcove, D. S., \& Wikelski, M. (2008). Going, going, gone: Is animal migration disappearing. PLoS Biology, 6(7), Article e188. https://doi.org/10.1371/journal.pbio.0060188

Wilson, H. B., Kendall, B. E., Fuller, R. A., Milton, D. A., \& Possingham, H. P. (2011). Analyzing variability and the rate of decline of migratory shorebirds in Moreton Bay, Australia. Conservation Biology, 25(4), 758-766. https://doi.org/10.1111/j.1523-1739.2011.01670.x

Wu, J., \& Shi, Y. (2016). Attribution index for changes in migratory bird distributions: The role of climate change over the past 50 years in China. Ecological Informatics, 31, 147-155. https://doi.org/10.1016/j. ecoinf.2015.11.013

Wuethrich, B. (2000). ECOLOGY: How Climate Change Alters Rhythms of the Wild? Science, 287(5454), 793-795. https://doi.org/10.1126/science.287.5454.793

Yang, H., Ma, M., Thompson, J. R., \& Flower, R. J. (2017). Protect coastal wetlands in China to save endangered migratory birds. Proceedings of the National Academy of Sciences, 114(28), E5491-E5492. https://www. pnas.org/content/114/28/E5491

Yorkston, H. D., \& Green, P. T. (1997). The breeding distribution and status of Abbott's booby (Sulidae: Papasula abbotti) on Christmas Island, Indian Ocean. Biological Conservation, 79(2-3), 293-301. https:// doi.org/10.1016/s0006-3207(96)00088-2

Zeuss, D., Brandl, R., Brändle, M., Rahbek, C., \& Brunzel, S. (2014). Global warming favours light-coloured insects in Europe. Nature Communications, 5(1), 1-9. https://doi.org/10.1038/ncomms4874

Zhao, M., Alström, P., Hu, R., Zhao, C., Hao, Y., Lei, F., \& Qu, Y. (2016). Phylogenetic relationships, song and distribution of the endangered Rufous-headed RobinLarvivora ruficeps. Ibis, 159(1), 204-216. https:// doi.org/10.1111/ibi.12426

Zöckler, C., Delany, S, \& Hagemeijer, W. (2003). Wader populations are declining-how will we elucidate the reasons? Wader Study Group Bulletin, 100, 202-211.

Zöckler, C., Beresford, A. E., Bunting, G., Chowdhury, S. U., Clark, N. A., Fu, V. W. K., Htin Hla, T., Morozov, V. V., Syroechkovskiy, E. E., Kashiwagi, M., Lappo, E. G., Tong, M., Long, T. L., Yu, Y. T., Huettmann, F., Akasofu, H. K., Tomida, H., \& Buchanan, G. M. (2016). The winter distribution of the Spoon-billed Sandpiper Calidris pygmaeus. Bird Conservation International, 26(4), 476-489. https://doi.org/10.1017/ s0959270915000295 
Zöckler, C., Hla, T., Clark, N., Syroechkovskiy, E., Yakushev, N., Daengphayon, S., \& Robinson, R. (2010a). Hunting in Myanmar is probably the main cause of the decline of the Spoon-billed Sandpiper Calidris pygmeus. Wader Study Group Bulletin, 117(1), 1-8.

Zöckler, C., Syroechkovskiy, E. E., \& Atkinson, P. W. (2010b). Rapid and continued population decline in the Spoon-billed Sandpiper Eurynorhynchus pygmeus indicates imminent extinction unless conservation action is taken. Bird Conservation International, 20(2), 95-111. https://doi.org/10.1017/s0959270910000316 
